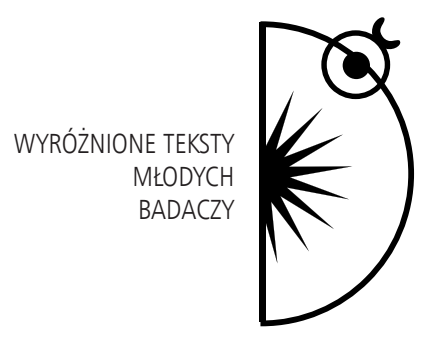

\title{
Recenzja artykułu: Wpływ ćwiczeń z kinezjologii edukacyjnej na skuteczność uczenia się słownictwa na lekcjach języka obcego
}

DOI: http://dx.doi.org/10.12775/PBE.2013.024

1. Zgodność z profilem czasopisma.

Zgodny.

2. Wkład do wiedzy.

Nowe informacje dotyczące skuteczności metody i weryfikacji koncepcji.

3. Wewnętrzna spójność tekstu.

Bez zastrzeżeń.

4. Ugruntowanie teoretyczne.

Wystarczające.

5. Metodologiczna poprawność.

Zaprezentowany artykuł omawia badania empiryczne wykonane w schemacie eksperymentalnym. Warto zwrócić uwagę, że autorki/rzy formułują hipotezę kierującą badaniem, która w sensie strukturalnym odpowiada cechom schematu eksperymentalnego. Wybór hipotezy był trafny, ponieważ jest to badanie weryfikacyjne, konfrontujące twierdzenie teoretyczne, a w każdym razie nieempiryczne z rzeczywistością edukacyjną. Są więc przesłanki i są zdefiniowane warunki, które muszą wystąpić, by hipoteza była przyjęta lub odrzucona. Jest to zatem poprawnie sformułowany wniosek logiczny z teorii, odniesiony do warunków empirycznych. Kolejna kwestia warta pochwały to planowanie eksperymentu, które od razu uwzględnia warunki analizy statystycznej. Autorki/ /rzy dbają o poziom pomiaru (interwałowy), ponieważ wiedzą, że wykorzystają jednoczynnikową wariancji Anova, która takiego poziomu wymaga. Podobnie 
są przewidujące w odniesieniu do warunków strategii ilościowej. Ponieważ ta zmierza do budowania ogólnych prawidłowości, planują losowy dobór do próbki, zyskując tym samym prawo do szacowania parametru. Co więcej, zachowują pierwszą i drugą zasadę randomizacji, co - z kolei - zabezpiecza warunki analizy wariancji. Zresztą w odniesieniu do tych warunków postępują konsekwentnie i weryfikują także założenie o jednorodności wariancji.

W części teoretycznej jest cytat, który budzi zastrzeżenia, a dotyczy krytyki metod kinezjoterapii. Otóż, nie jest to w zasadzie analiza krytyczna, lecz zbiór ocen operujących ogólnymi pustymi, hasłami, np.: „opisy procesów i zasad funkcjonowania mózgu zawarte w publikacjach kinezjologii edukacyjnej nie mają sensu z punktu widzenia naukowego". Nasuwa się pytanie, czy cytowana autorka pisze o tym tylko w taki sposób, czy może autorki/rzy artykułu ten akurat fragment - nieszczęśliwie - cytują, podczas gdy w oryginale są szczegółowe wyjaśnienia dotyczące tej kwestii. Jeśli jest to cała krytyka, to nie warto jej cytować czy przywoływać. Nic nie wnosi ona do recepcji metody kinezjoterapii, ponieważ nie poddaje jej merytorycznej analizie. Jeśli natomiast w oryginale występują argumenty merytoryczne, to należy je pokazać, zamiast cytować te ogólne oceny. Z tą kwestią łączy się także inny problem. Autorki/rzy piszą, że zarówno ich, jak i inne badania sprawiają, że analizy krytyczne dotyczące metody kinezjoterapii są bezpodstawne. Otóż, występuje tu problem z rozumieniem przedmiotu weryfikacji, jakim zajęły się autorki omawianego tekstu. Trzeba podkreślić, że te badania sprawdzały skuteczność samej metody i jako takie nie mogą stanowić kryterium do oceny argumentów krytycznych dotyczących szczegółowych kwestii związanych z funkcjonowaniem mózgu czy w ogóle z recepcją kinezjoterapii. Autorki/rzy wykraczają poza obszar swoich badań i dokonują nieuprawnionej ekstrapolacji ich wyników. W części „wnioski z badania" autorki/rzy przywołują badania nad skutecznością kinezjoterapii, prowadzone przez innych badaczy/czki. Jednak nie piszą, jakie przyniosły rezultaty i na czym polegały. Otóż, jest to tak samo perswazyjne jak analizowany powyżej cytat i wymaga doprecyzowania. W ostatnim natomiast fragmencie tekstu autorki/rzy nadmiernie wychwalają metodę kinezjoterapii, zaburzając nieco jego empiryczny charakter. Przywołują treści, które mogą być bardziej kojarzone z marketingiem tej metody niż jej rzeczową analizą. W niektórych miejscach brakuje też przypisów.

6. Uwzględnienie literatury przedmiotu.

Wystarczające.

7. Formalna i redakcyjna poprawność (stylistyczna, gramatyczna, edycyjna). Poprawny. 
Recenzent przedstawia uwagi krytyczne i rekomenduje bądź nie rekomenduje tekst do druku. Możliwe rekomendacje to:

a) przyjąć do druku w obecnej postaci,

b) przyjąć do druku bez ponownej recenzji pod warunkiem naniesienia poprawek,

c) przyjąć do druku pod warunkiem naniesienia poprawek i ponownego przedstawienia do recenzji,

d) nie przyjąć. 